IJMS 18 (2), 23-41 (2011)

\title{
COMPETITIVENESS OF MALAYSIA: A COMPARATIVE STUDY
}

\author{
P. R. BHATT \\ UUM College of Business \\ Universiti Utara Malaysia
}

\begin{abstract}
The objective of this paper was to study the competitiveness of Malaysia in comparison with some countries like Indonesia, the Philippines, Singapore, Thailand, and Vietnam. The study analysed the competitiveness of Malaysia in terms of four parameters viz. Global competitive index ranking; Total, labour and capital productivity; Foreign direct investment inflows, and Trade competitiveness in terms of the cost of production. It is found that the domestic cost of production of exports of Malaysia has become competitive in 2007 and 2009. The study shows that Malaysia's competitiveness has improved especially in the later part of 2000. There is a need to improve the competitiveness of Malaysia by focusing on research and innovation which can be achieved through collaboration of research institutions and industry.
\end{abstract}

Keywords: Malaysia, competitiveness, productivity, mergers and acquisition, price index.

JEL classifications: F10, F13

\section{Introduction}

Malaysia is a growing economy with a gross domestic product (GDP) of US $\$ 222$ billion and per capita GDP of US\$ 8140 in $2008^{1}$. It has a population of 27 million people with a growth rate of $1.7 \%$ per annum in $2008^{2}$. It follows free-market forces to drive its economy with exports as the prime growth engine. The five-year plans framework remains the basis of formulation and implementation of the economic programmes to achieve short-term and long-term growth. The New Economic Policy (NEP) of 1970 was targeted to eradicate poverty and to improve the distribution of wealth among the country's population. Later the government of Malaysia adopted the National Development Policy (NDP) to take the economy to a higher level in 1991. The main thrust of the policy was to promote the private sector and to develop 
human resource capacity. Privatisation of inefficient state-owned enterprises and creation of an entrepreneurial environment has led the economy to achieve a high GDP growth rate of $8.5 \%$ in the $1990 \mathrm{~s}^{3}$. During this period, the economy had become a hub for high technology manufacturing exports. When the economy was opened in 1991, foreign funds were attracted to the country which created an opportunity for local businesses to raise capital in the capital market. The foreign direct investment together with the growth of local businesses led to the development of infrastructure like highways, power generation, telecommunications, etc. in the country. Malaysia has become a vibrant manufacture-based economy with the industry sector contributing $47.6 \%$ in GDP with a growth of $11.5 \%$ in $2008^{4}$. Malaysia has successfully transformed its manufacturing sector from state controlled to market-oriented through price deregulation, ownership reform of state-owned enterprises, private sector development of foreign direct inflow (FDI) and trade liberalization. The government of Malaysia's attitude towards the private sector and FDI helped the country to enter the second stage of development. In 2005, the fixed exchange-rate regime was abandoned and a floating regime was announced to reduce vulnerability of the currency and to expose the export sector to greater competition and enhance productivity in the capital-intensive industry.

Malaysia's average annual GDP growth rate was $4.6 \%$ against Indonesia's 6.1\%, the Philippine's 3.8\%, Singapore's 1.1\%, Thailand's $2.5 \%$, and Vietnam's $6.2 \%$ in 2008 . The annual GDP of Malaysia has fallen from $5.3 \%$ in 2005 to $4.6 \%$ in $2008^{6}$. The moderate growth achieved by Malaysia was because of the government policy towards private enterprises and foreign direct investment. The government of Malaysia has adopted entrepreneur-friendly policies which helped private entrepreneurs to invest heavily to take advantage of the opportunity available in the economy. The GDP per capita for Malaysia was US\$ 8140 against US\$ 2246 for Indonesia, and US\$ 38972 for Singapore 7 . The per capita growth of Malaysia has fallen from $4.8 \%$ in 2004 to $2.8 \%$ in 2008 mainly due to world recession and increase in competition from China and South $\mathrm{Korea}^{8}$. Malaysia had improved its exports growth from $12 \%$ in 2005 to $19.1 \%$ in 2008 and imports growth from $8.7 \%$ to $12 \%$ during the same period ${ }^{9}$. Malaysia considered exports as the engine of growth of the economy. The major exports of Malaysia are electronic equipment, petroleum and liquefied natural gas, wood and wood products, palm oil, rubber, textiles and chemicals. The major imports are electronics, machinery, petroleum products, plastics, vehicles, iron \& steel products and chemicals. In the share of exports in the world's exports, Malaysia stood second $(1.4 \%)$ behind Singapore $(2.2 \%)$ in $2005^{10}$. The share of exports of Malaysia in its GDP was 121\% compared to Singapore's $234 \%$ and 
imports $95.6 \%$ as compared to Singapore's $215 \%$ in $2008^{11}$. Imports of Malaysia played a significant role to boost exports and investment.

In Malaysia, the industry sector dominated with $47.6 \%$ of the GDP followed by the service sector $(42.3 \%)$ and the agriculture sector $(10.1 \%)$ in $2008^{12}$. The industry sector in Malaysia grew $7 \%$ whereas the service sector grew only $5 \%$ and the agriculture sector $6 \%$ in $2003^{13}$. The high industry-sector growth resulted in high overall growth of the economy. The high industry growth also resulted in high FDI inflow as FDI is normally attracted to the industry sector (Bhatt 2008a). Manufacturing is the engine of growth as industrial goods have a higher-income elasticity of demand (Kaldor, 1967). The growth of the manufacturing sector resulted in faster growth of the GDP of Malaysia. It pursued a dynamic industrial policy to encourage industries through trade and investment. It invested heavily on infrastructure. It is important to see that in Malaysia the service sector also grew in tandem with the industry sector because any significant imbalance between the two affect consumption and investment efficiency.

The objective of this paper is to study the competitiveness of Malaysia in comparison with its neighbours and to know where Malaysia stands among them.

The paper is organized as follows. Following this introduction Section 2 surveys the literature on competitiveness. Section 3 analyses the parameters of competitiveness. Section 4 concludes the discussion.

\section{Survey of Literature on Competitiveness}

Competitiveness is the ability of an economy's GNP and the GNP per capita to grow as fast as another major economy (Jones and Teece, 1988). National competitiveness is the ability to produce and distribute products and/or services that can compete in international markets and simultaneously increase the real incomes and living standards of the nation's citizens (Blaine, 1993). Adam Smith (1776) states in his theory of absolute advantage that the one who is able to produce with the lowest cost in the world has the absolute advantage and thereby it determines the basis of competitiveness. Ricardo (1817) proposed a comparative advantage trade model. According to him international trade is created by the difference of labour productivity in countries. Heckscher-Ohlin $(1919,1933)$ propounded differences in factor endowments to explain trade flows between countries. It means that a region should specialise in products, the production costs of which are relatively low because the factors of production are 
abundant. Vernon (1966), Krugman $(1983,1986)$, Porter (1990) argued that deployment of factors rather than factors themselves explained competitiveness of a country. Porter (1990) explained competitiveness in terms of the quality of demand conditions, nature of competition, quality of factors of production and the extent of supporting industries. Bartlett and Ghoshal (1989), Prahalad and Doz (1987) and Prahalad and Hamel (1990) explained competitiveness in terms of strategies for global operations. Porter (1990) explained competitiveness in terms of productivity. "A nation's standard of living is determined by the productivity of its economy, which is measured by the values of goods and services produced per unit of the nation's human, capital, and natural resources" (Porter \& Ketels, 2003). Long-run productivity growth, higher savings and investment rates, government's emphasis on quantity and quality of education and investment in infrastructure were responsible for the high rate of growth in Japan (Baumol \& Mclennan, 1985). Choudhri and Schembri (2002) found a robust positive link between productivity performance and international competitiveness in the US and the Canadian industries. Caves (1974), Globerman (1979), Blomstrom and Persson (1983) found technological spillovers in the host country's sector through FDI. Aitken and Harrison (1999) using a panel data from Venezuela covering the period between 1976-89 and more than 3000 firms found a "negative spillover effect" on domestic firms which tends to be bigger for smaller firms. Djankov and Hoekman (1999) also found a negative spillover effect of FDI on purely domestic firms in the Czech industry. Chung et al. (1998) found no positive impact on the Japanese FDI in the automotive sector on the American components-suppliers. Girma and Wakelin (2001) found for the electronics sector in the UK, a positive impact of FDI investments on domestic firms located in the same region. Javorcik and Spatarareanu (2003) found that MNCs were likely to transfer more technology to their wholly-owned subsidiaries than to partially-owned ones because of fears of technology leakages. Driffield and Love (2005) found that the UK gains substantially only from inward FDI motivated by a strong technology-based ownership advantage. They also found that inward FDI motivated by technology-sourcing consideration leads to no productivity spillovers and the same is true of 'efficiency-seeking' inward FDI. Price has an important influence on competitiveness. The usual approach to the subject of price competitiveness is by the "relative" method; that is analysing the changes in comparative export prices, relative to the changes in the supplier's export performance (McGeehan, 1968). Junz and Rhomberg (1964) found that $43 \%$ of the variation in export shares can be attributed to relative export prices. Parkinson (1966) found a positive association between price and export performance. Growth in relative unit labour cost is the most popular measure of international competitiveness. Fagerberg (1988) found that the main 
factors influencing differences in international competitiveness and growth across countries are technological competitiveness and the ability to compete on delivery. Cost competitiveness does affect competitiveness and growth to some extent, but less so than many seem to believe (Fagerberg, 1988). Lamfalussy (1963) found that unit labour costs rose more rapidly in the U K over the period 1953-60 than elsewhere because of the growth of productivity (output per manhour).

\section{Competitiveness of Malaysia}

In this paper an attempt has been made to measure competitiveness of Malaysia in terms of four parameters. They are:

1. Global competitive index ranking.

2. Total, labour and capital productivity.

3. Foreign direct investment inflows.

4. Trade competitiveness in terms of cost of production.

\section{Global Competitive Index Ranking}

World Economic Forum's (2008) global competitive index was constructed by taking into account the many parameters such as institutions, infrastructure, macroeconomic stability, health and primary education, higher education and training, goods-market efficiency, labour-market efficiency, financial-market sophistication, technological readiness, market size, business sophistication and innovation. Based on the global competitive index, Malaysia was ranked 24 which was second among its neighbouring countries. Singapore was the first whose rank was 3, Thailand 36, Indonesia 54, Vietnam 75 and the Philippines 87 among the 133 countries in 2009-10 (Table 1 \& Exhibit 1). Malaysia remained second in all pillars of competition among its neighbouring countries; the first being Singapore except in market size (Table 1). Malaysia's competitiveness was affected by institutional deficiency (43rd rank), macroeconomic stability (42nd rank) and inadequacy of higher education and training (41st rank). It has to improve infrastructure and technology in order to compete with global players. Singapore was globally competitive in building institutions (1st rank), market and labour efficiency (1st rank) and financial-market efficiency (2nd rank). Singapore has faced the problems of market economic stability and market size. Inefficient government bureaucracy and corruption are the main problematic factors responsible for doing business in Malaysia. Business sophistication and innovation are the other areas to be strengthened to climb up the ladder of the competitive index further.

IJMS 18 (2), 23-41 (2011) 27 


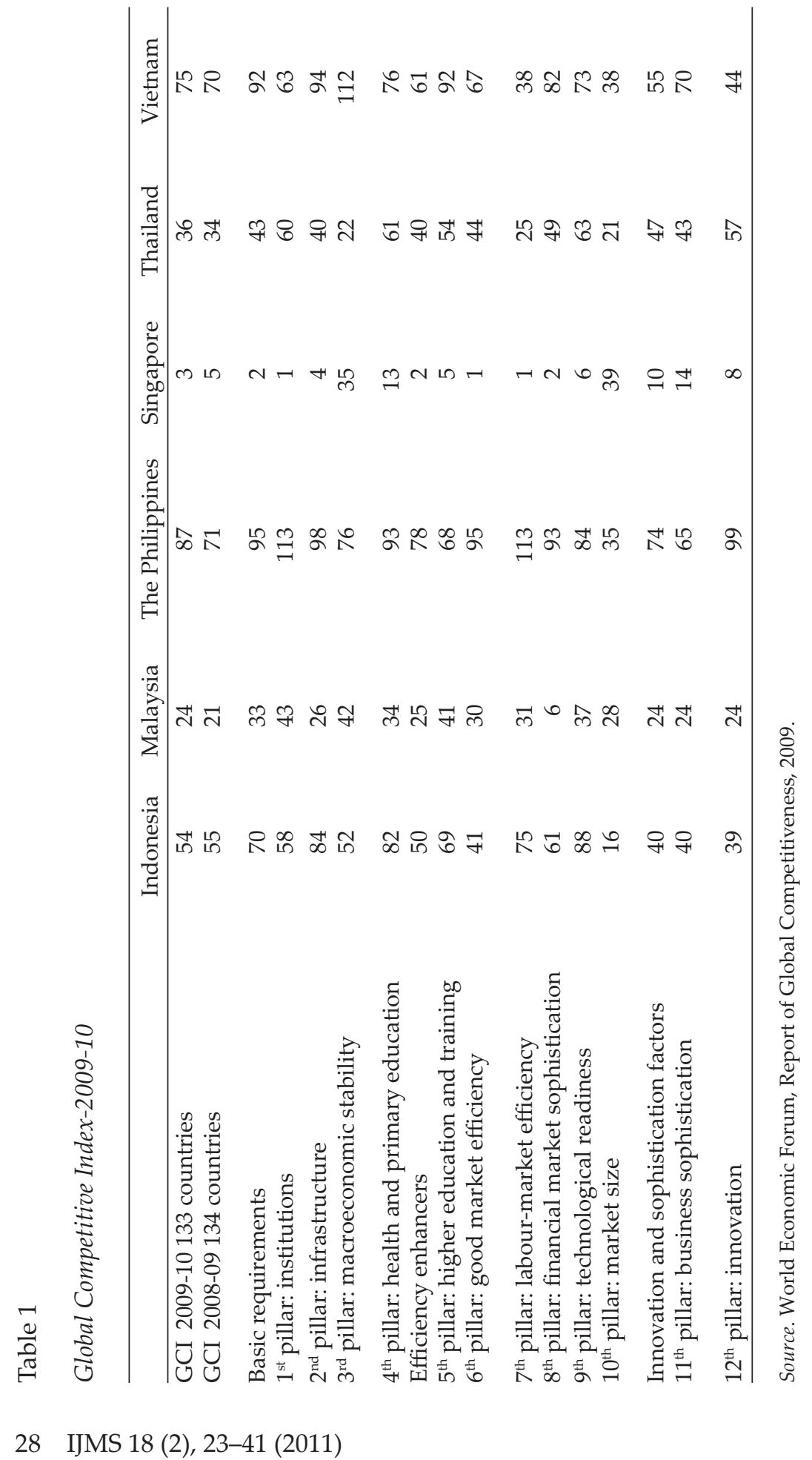


Exhibit 1: Global competitive index ranking-2009-2010

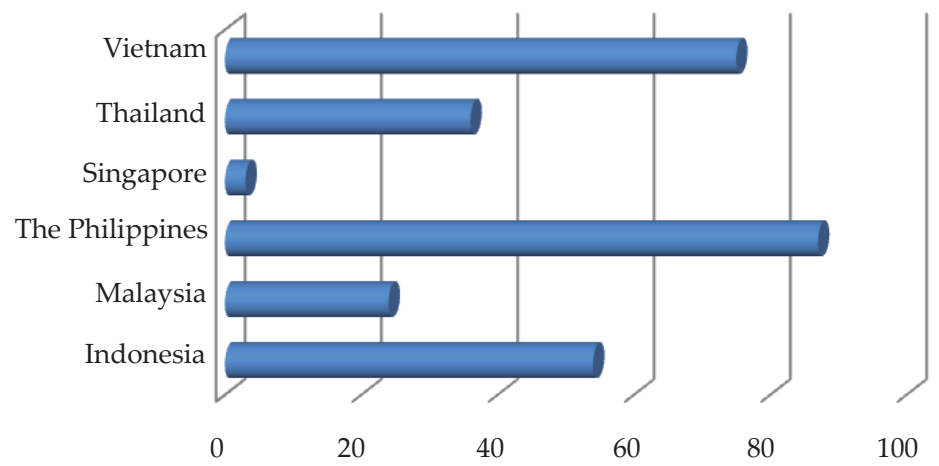

Note. Ranking 1 indicates the highest competitiveness and ranking 100 indicates the lowest competitiveness of a country.

\section{Total, Labour and Capital Productivity}

Productivity is one of the measures of competitiveness. "A nation's standard of living is determined by the productivity of its economy, which is measured by the values of goods and services produced per unit of the nation's human, capital, and natural resources (Porter \& Ketels, 2003). Over the long period of 1960-2002, the average output growth rate per worker for Malaysia was $0.09 \%$ which was very low compared to its neighbouring countries. The improvement of labour productivity has an impact on the performance of the economy. The average capital growth rate per worker was also as low as $0.04 \%$. Malaysia adopted capital-intensive techniques and tried to improve capital productivity in the 2000s. The average human capital was $2.1 \%$ which was comparable to its neighbours (Table 2). The total factor productivity growth for Malaysia during the same period was only $0.31 \%$. But it increased to $1.5 \%$ during $2000-2009^{14}$. The total productivity growth rate of Malaysia increased from 2.98\% in 2005 to $4.17 \%$ in 2007 but fell to $-1.84 \%$ in 2009 (Table 3 \& Exhibit 2). The fall in total productivity-growth was due to the fall in the productivity-growth rate in manufacturing from $2.01 \%$ to $-8.58 \%$ during the same period. In 2009, only Indonesia (2.6\%) was above Malaysia $(-1.84)$ in the total productivity-growth rate among its neighbours ${ }^{15}$. The productivity-growth rate for the other countries are 
the Philippines $-2 \%$, Thailand $-3.7 \%$ and Singapore $-4.1 \%$ in $2009^{16}$. Labour productivity in Malaysia also fell from 1.68\% during 2000-04 to $1.47 \%$ during $2000-09$ and capital productivity fell from $2.14 \%$ to $1.76 \%$ during the same period (Table 4 \& Exhibit 3 ).

Table 2

Average Growth of Output and Input

\begin{tabular}{lccccccc}
\hline Country & \multicolumn{5}{c}{ Growth rate per worker } & \multirow{2}{*}{ TFP } & $\begin{array}{c}\text { TFP relative } \\
\text { to output }\end{array}$ \\
\cline { 2 - 5 } & $\begin{array}{l}\text { First } \\
\text { year }\end{array}$ & Output & Capital & $\begin{array}{c}\text { Human } \\
\text { Capital }\end{array}$ & \\
\hline Indonesia & 1951 & 0.31 & -0.1 & 1.72 & 0.78 & -0.44 \\
Malaysia & 1960 & 0.09 & 0.04 & 2.1 & 0.31 & -0.1 \\
The Philippines & 1939 & 0.53 & 0.11 & 1.95 & 0.09 & 0.04 \\
Singapore & 1963 & 0.38 & 0.15 & 2.67 & 0.53 & 0.11 \\
Thailand & 1937 & -1.8 & -1.17 & 1.32 & 0.38 & 0.15 \\
Vietnam & 1980 & 0.28 & 0.21 & 2.75 & -1.8 & -1.17 \\
\hline
\end{tabular}

Note. The end year is 2000 .

Source. Scott L, Baier, Gerald P. Dwyer Jr., and Robert Tamura (2002). How important are capital and total factor productivity for economic growth? Federal Reserve Bank of Atlanta, Working Paper 2002-2.

Table 3

Productivity Growth (\%) in Malaysia: 2005-09

\begin{tabular}{lccccc}
\hline & 2005 & 2006 & 2007 & 2008 & 2009 \\
\hline Agriculture & 2.58 & 3.41 & 2.8 & 3.01 & 0.36 \\
Manufacturing & 3.76 & 4.42 & 2.65 & 2.01 & -8.59 \\
Service & 2.9 & 3.12 & 5.08 & 3.2 & 1.65 \\
Overall & 2.98 & 3.68 & 4.17 & 2.89 & -1.84 \\
\hline
\end{tabular}

Source. Malaysia Productivity Corporation, Productivity Performance of Malaysia, Key Productivity Statistics.

30 IJMS 18 (2), 23-41 (2011) 


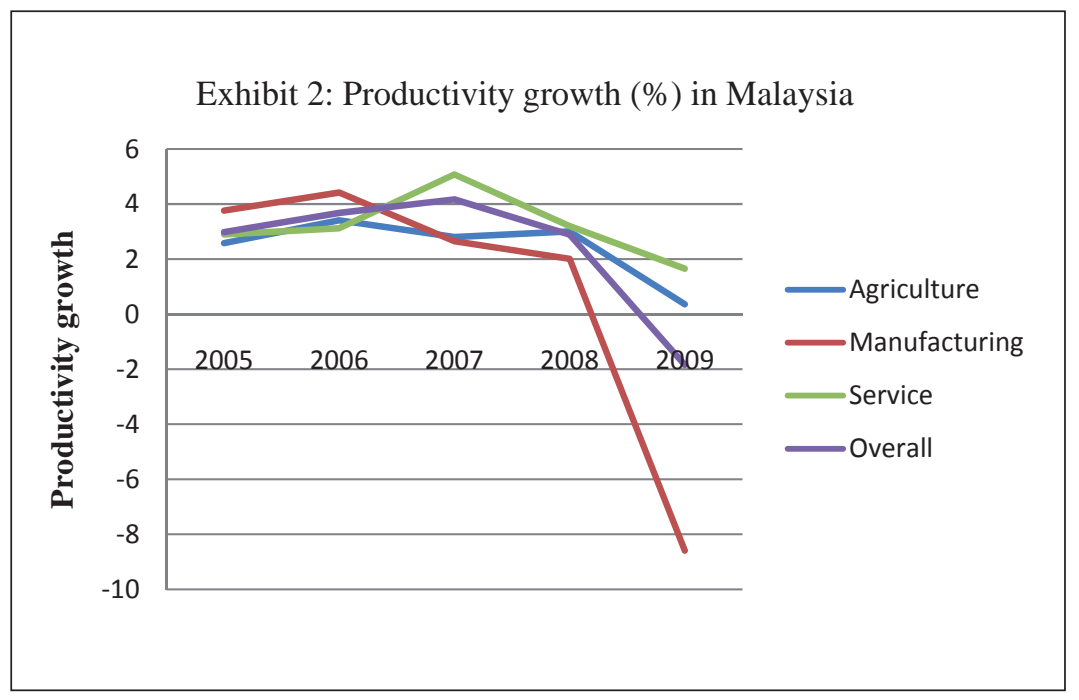

Table 4

Growth of Labour and Capital Productivity (\%)

\begin{tabular}{ccccc}
\hline & $2005-09$ & $2000-04$ & $2004-08$ & $2000-09$ \\
\hline Labour & 1.26 & 1.68 & 1.58 & 1.47 \\
Capital & 1.38 & 2.14 & 2.27 & 1.76 \\
\hline
\end{tabular}

Source. Malaysia Productivity Corporation, Productivity Performance of Malaysia, Key Productivity Statistics.

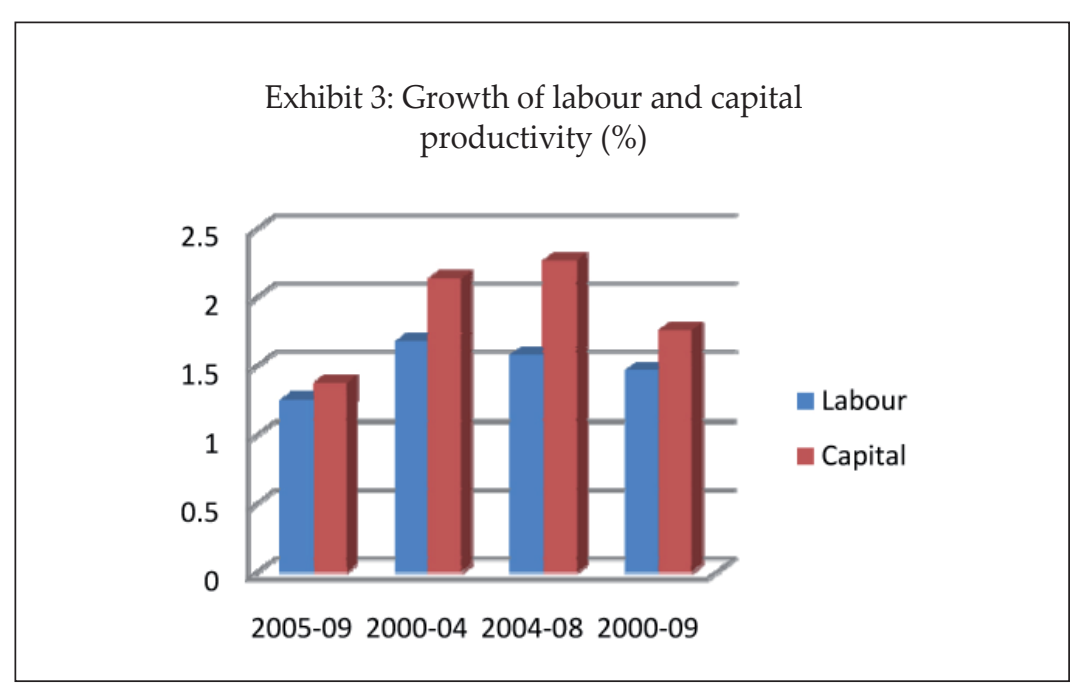

IJMS 18 (2), 23-41 (2011) 31 


\section{Foreign Direct Investment (FDI) Inflows}

FDI inflows can be considered as another measure of competitiveness of a nation. High FDI inflows would contribute a high level of investments and employment generation, raising productivity and skill development and sharply improving competitiveness (Bhatt, 2008b). Malaysia is an open economy with low barriers for trade and foreign direct investment. FDI in Malaysia was both efficiency-seeking and market-seeking which helped the expansion of manufacturing and trade in Malaysia. The main challenge for Malaysia is to make connections with international production systems by attracting sufficient FDI inflows. FDI inflows for Malaysia were US\$ 1.4 billion in 2009. Singapore attracted the highest FDI inflows to the tune of US $\$ 16.8$ billion in 2009 (Table 5). FDI inward stock was US\$ 75 billion where it was US\$ 344 billion for Singapore in 2009 (Table 6). Malaysia was third in FDI inward stock among its neighbours in 2009. FDI inflows have contributed immensely in its industrial structure. Malaysia has adopted an investment-led industrial policy which helped foreign investors to invest in Malaysia in a big way. FDI inflows as a percentage of the gross fixed capital formation was 3.5\% for Malaysia and 32.9\% for Singapore (Table 7) in 2009 . The ratio of FDI inflows gross fixed capital formation was $21.2 \%$ in $2007^{17}$. Even though Malaysia has encouraged FDI inflows, it made sufficient surplus internally to finance its manufacturing sector. The stock of FDI inflows as a percentage of the Gross Domestic Product was 39\% for Malaysia and was the highest at 194\% for Singapore in 2009 (Table 8). Malaysia increased the percentage from $32.2 \%$ in 2005 to $39 \%$ in 2009 which was very significant. Sales of mergers and acquisitions for Malaysia were US\$ 354 million in 2009 whereas for Singapore it was US\$ 9.7 billion, and for Indonesia US\$ 6.1 billion (Table 9). Sales of mergers and acquisitions were US\$ 2.8 biilion in $2008^{18}$. In 2000 many multinational companies entered the country through $M$ \& As to take advantage of the existing opportunities. The purchase of cross-border mergers and acquisitions was US\$ 3.3 billion for Malaysia and Singapore in 2009 (Table 10). Malaysia's capability to pull global resources in the form of physical capital and know-how has indicated its advantage of production conditions. 
Table 5

FDI Inflows (Millions of \$)

\begin{tabular}{ccccccc}
\hline Year & Indonesia & Malaysia & The Philippines & Singapore & Thailand & Vietnam \\
\hline 1990 & 1092 & 2611 & 550 & 5575 & 2575 & 180 \\
1995 & 4419 & 5815 & 1459 & 11535 & 2070 & 1780 \\
2000 & -4495 & 3788 & 2240 & 16484 & 3410 & 1289 \\
2005 & 8337 & 4064 & 1854 & 15460 & 8967 & 2021 \\
2009 & 4877 & 1381 & 1948 & 16809 & 5949 & 4500 \\
\hline
\end{tabular}

Source. UNCTAD: World Investment Report, 2009.

Table 6

Stock of FDI Inflows (Billions of \$)

\begin{tabular}{ccccccc}
\hline Year & Indonesia & Malaysia & The Philippines & \multicolumn{2}{r}{ Singapore } & Thailand \\
\hline 1990 & 8.7 & 10.3 & 4.5 & 30.5 & 8.2 & 1.7 \\
1995 & 20.6 & 28.7 & 10.1 & 65.6 & 17.7 & 7.2 \\
2000 & 25.1 & 52.7 & 18.2 & 110.6 & 29.9 & 20.6 \\
2005 & 41.2 & 44.5 & 15.0 & 194.6 & 60.4 & 31.1 \\
2009 & 72.8 & 74.6 & 23.6 & 343.6 & 99.0 & 52.8 \\
\hline
\end{tabular}

Source. UNCTAD: World Investment Report, 2009.

Table 7

FDI Inflows as a Percentage of Gross Fixed Capital Formation

\begin{tabular}{ccccccc}
\hline Year & Indonesia & Malaysia & The Philippines & Singapore & Thailand & Vietnam \\
\hline 1990 & 3.4 & 17.9 & 5.4 & 46.8 & 7.5 & 21.2 \\
1995 & 7.7 & 15.0 & 8.9 & 41.1 & 3.0 & 33.8 \\
2000 & -13.7 & 16.0 & 13.9 & 58.1 & 12.6 & 15.0 \\
2005 & 12.3 & 14.4 & 13.0 & 60.0 & 15.8 & 11.6 \\
2009 & 2.9 & 3.5 & 8.2 & 32.9 & 9.2 & 12.8 \\
\hline
\end{tabular}

Source. UNCTAD: World Investment Report, 2009.

IJMS 18 (2), 23-41 (2011) 33 
Table 8

Inward FDI Stock as a Percentage of Gross Domestic Product

\begin{tabular}{|c|c|c|c|c|c|c|}
\hline & Indonesia & Malaysia & The Philippines & Singapore & Thailand & Vietnam \\
\hline 1990 & 6.9 & 23.4 & 10.2 & 82.6 & 9.7 & 25.5 \\
\hline 1995 & 9.3 & 32.3 & 13.7 & 78.2 & 10.5 & 34.5 \\
\hline 2000 & 15.2 & 56.2 & 24.2 & 119.3 & 24.4 & 66.1 \\
\hline 2005 & 14.4 & 32.2 & 15.2 & 160.5 & 34.2 & 58.8 \\
\hline 2009 & 13.5 & 39.0 & 14.6 & 194.0 & 37.5 & 51.9 \\
\hline
\end{tabular}

Source. UNCTAD: World Investment Report, 2009.

Table 9

Value of Cross-border MEA Sales (Millions of dollars)

\begin{tabular}{rrrrrrr}
\hline & Indonesia & Malaysia & The Philippines & Singapore & Thailand & Vietnam \\
\hline 1990 & 0 & -186 & 15 & 461 & -1 & 0 \\
1995 & 227 & -129 & 285 & -5 & 183 & 0 \\
2000 & 96 & 976 & -958 & 1309 & 2104 & 10 \\
2005 & 6171 & 1141 & -5180 & 3933 & -632 & 10 \\
2009 & 1332 & 354 & 1291 & 9693 & 346 & 230 \\
\hline
\end{tabular}

Source. UNCTAD: World Investment Report, 2009.

Table 10

Value of Cross-border MEA Purchases (Millions of dollars)

\begin{tabular}{rrrrrrr}
\hline & Indonesia & Malaysia & The Philippines & Singapore & Thailand & Vietnam \\
\hline 1990 & 194 & 58 & 0 & 88 & 38 & 0 \\
1995 & 97 & 968 & 85 & -366 & 181 & 0 \\
2000 & 131 & 236 & 73 & 8013 & 21 & 0 \\
2005 & 290 & 1946 & 1829 & 5706 & -203 & 0 \\
2009 & -2590 & 3277 & -7 & 3332 & 872 & 0 \\
\hline
\end{tabular}

Source. UNCTAD: World Investment Report, 2009.

34 IJMS 18 (2), 23-41 (2011) 


\section{Trade Competitiveness in Terms of Cost of Production}

Wholesale price index can be considered as a proxy for the cost of production (Doggett \& Cresswell, 1979). Competitiveness in terms of the cost of production can be assessed by the relative wholesale prices index (RWPI) (Doggett \& Cresswell, 1979). The relative wholesale-price index is a country's wholesaleprice index divided by a simple average of the wholesale-price indices of its competitors. The relative wholesale-price index is worked out for Indonesia, Malaysia, the Philippines, Singapore, and Thailand.

Malaysia's major export destination is given in Table 11. China was the top destination of Malaysia's exports in 2010 followed by Japan, the USA, the Republic of Korea, Australia and Netherland. During 2005-2008, the USA was the top export destination followed by Japan. However, China replaced the top position during 2009-10. The export destinations of Indonesia, the Philippines, Singapore and Thailand are given in Table 12. Japan was the top destination of exports for Indonesia whereas the USA was the top destination of exports for the Philippines and Thailand. In the case of Singapore, Hong Kong remained the top destination of exports.

The data used for the study were taken from IMF, International Financial Statistics, and Annual. The relative wholesale-price indices of the five countries are presented in Table 13 and Exhibit 1. The relative wholesale-price index of a country (RWPI) is computed as the wholesale-price index of the country divided by a simple average of the wholesale-price index of the other four countries. If the RWPI is below 100 it means more competitiveness in the domestic cost of production and above 100 indicates less competitiveness. Here we have taken the wholesale-price index as a proxy for the domestic cost of production. Malaysia remained competitive in terms of the domestic cost of production only in 2007 and 2009 (Table 12 and Exhibit 4). Indonesia and the Philippines were competitive during 1994-2003 and Indonesia lost its competitiveness since then whereas the Philippines returned to competitiveness since 2008. Singapore and Thailand enjoyed competitiveness during 2006-2010. 
Table 11

Malaysia's Top Destination of Exports in Percentage

\begin{tabular}{lcccccc}
\hline Destination & 2010 & 2009 & 2008 & 2007 & 2006 & 2005 \\
\hline $\begin{array}{l}\text { Total Exports } \\
\text { (RM in billions) }\end{array}$ & 639.4 & 553.3 & 663.5 & 605.1 & 559.0 & 533.8 \\
Singapore & 13.4 & 14.0 & 14.7 & 14.6 & 15.4 & 15.6 \\
China & 12.6 & 12.2 & 9.5 & 8.8 & 7.2 & 6.6 \\
Japan & 10.4 & 9.8 & 10.8 & 9.1 & 8.9 & 9.4 \\
The USA & 9.5 & 10.5 & 12.5 & 15.6 & 18.8 & 19.7 \\
Thailand & 5.3 & 5.4 & 4.8 & 5.0 & 5.3 & 5.4 \\
Hong Kong & 5.1 & 5.2 & 4.3 & 4.6 & 4.9 & 5.8 \\
The Rep. of Korea & 3.8 & 3.8 & 3.9 & 3.8 & 3.6 & 3.4 \\
Australia & 3.8 & 3.5 & 3.7 & 3.4 & 2.8 & 3.4 \\
Netherlands & 3.2 & 3.3 & 3.5 & 3.9 & 3.6 & 3.3 \\
\hline
\end{tabular}

Source. Ministry of International Trade and Industry, Malaysia.

Table 12

Top Destination of Exports of ASEAN Countries in Percentage-2009

\begin{tabular}{|c|c|c|c|c|c|}
\hline Destination & Indonesia & The Philippines & Singapore & Thailand & Malaysia \\
\hline $\begin{array}{l}\text { Total Exports } \\
\text { (US\$ in billions) }\end{array}$ & 119.5 & 37.6 & 268.9 & 151.9 & 163.2 \\
\hline Singapore & 11.3 & 6.2 & - & NA & 13.4 \\
\hline China & 7.6 & 7.7 & 9.7 & 10.6 & 12.6 \\
\hline Japan & 17.3 & 16.2 & 4.6 & 10.3 & 10.4 \\
\hline The USA & 10.8 & 17.6 & 11.2 & 10.9 & 9.5 \\
\hline Hong Kong & 5.5 & 8.6 & 11.6 & 6.2 & 5.1 \\
\hline
\end{tabular}

Source. Central Intelligence Agency: World Fact Book.

36 IJMS 18 (2), 23-41 (2011) 
Table 13

Relative Wholesale Price Index (RWPI) of Major ASEAN Countries

\begin{tabular}{lccccc}
\hline & Indonesia & The Philippines & Singapore & Thailand & Malaysia \\
\hline 1994 & 61.82 & 81.09 & 146.27 & 101.76 & 117.48 \\
1995 & 66.32 & 81.47 & 136.80 & 105.62 & 116.02 \\
1996 & 69.35 & 86.67 & 130.72 & 103.49 & 114.34 \\
1997 & 36.58 & 92.04 & 136.87 & 116.72 & 132.15 \\
1998 & 69.88 & 89.40 & 110.29 & 113.79 & 120.16 \\
1999 & 77.46 & 94.22 & 111.30 & 105.20 & 113.63 \\
2000 & 83.06 & 89.60 & 106.71 & 102.55 & 109.55 \\
2001 & 95.41 & 90.08 & 111.59 & 103.23 & 100.21 \\
2002 & 96.12 & 91.72 & 106.71 & 102.68 & 103.07 \\
2003 & 93.56 & 96.18 & 103.58 & 102.23 & 104.64 \\
2004 & 94.32 & 100.99 & 100.30 & 100.85 & 103.63 \\
2005 & 100.00 & 100.00 & 100.00 & 100.00 & 100.00 \\
2006 & 105.79 & 102.75 & 95.76 & 98.14 & 97.69 \\
2007 & 125.44 & 101.33 & 95.53 & 76.03 & 103.87 \\
2008 & 140.73 & 93.01 & 91.33 & 77.08 & 102.27 \\
2009 & 157.79 & 95.64 & 79.82 & 77.09 & 97.64 \\
2010 & 157.29 & 86.44 & 81.13 & 82.47 & 100.31 \\
\hline
\end{tabular}

Source. Computed-based data from IMF: International Financial Statistics.

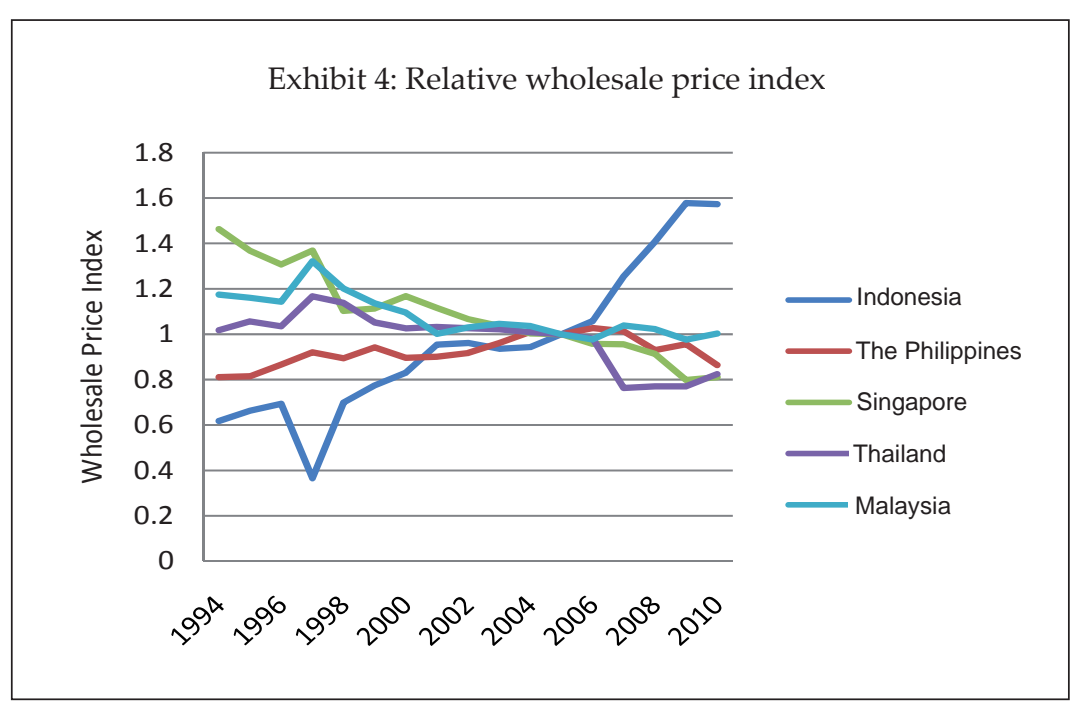

IJMS 18 (2), 23-41 (2011) 37 


\section{Conclusion}

The Malaysian economy was open and grew at a rate of $4.6 \%$ in 2008 . Its per capita income was US\$ 8140 which grew at $2.8 \%$ in 2008.The annual growth rate of exports and imports of goods and services were $19.1 \%$ and $12 \%$ respectively in 2008 . The share of exports in the world exports was $1.4 \%$ whereas it was less than $1 \%$ for India. Exports play an important role to boost the economy. Exports and imports as a percentage of GDP was $121 \%$ and $96 \%$ respectively in 2008 which was very significant. The manufacturing sector contributed $48.5 \%$ in its GDP whereas the service sector contributed $41.8 \%$ and the agricultural sector $9.7 \%$ in 2003 . Agriculture grew at a rate of $5.7 \%$, manufacturing at $7.2 \%$ and service at $3.5 \%$. In the global competitive index, Malaysia was ranked 24 out of 133 countries in 2009-10. The overall productivity-growth rate increased from $3 \%$ in 2005 to $4.2 \%$ in 2007 but fell to $-1.8 \%$ in 2009 . The fall in the overall growth of productivity was due to the fall in the productivity growth in manufacturing from $2 \%$ to $-8.6 \%$.FDI inflows for Malaysia were US $\$ 8.5$ billion in 2007 but fell to US\$ 1.4 billion in 2009. FDI inflows as a percentage of the gross fixed capital formation were $3.5 \%$ and the stock of FDI inflows as a percentage of the Gross Domestic Product was $13.5 \%$ in 2009. The domestic cost of production of the exports of Malaysia became competitive in 2007 and 2009. The study shows that Malaysia's competitiveness improved especially in the later part of 2000. There is a need to improve the competitiveness of Malaysia by focusing on research and innovation which can be achieved through the collaboration of the research institutions and the industry.

\section{End Notes}

1. World Bank. World Development Indicators, 2009.

2. ibid.

3. World Bank. World Development Indicators, 2009.

4. UNCTAD. Global Investment Report, 2009.

5. ibid World Bank.World Development Indicators, 2009.

6. ibid.

7. ibid.

8. ibid.

38 IJMS 18 (2), 23-41 (2011) 
9. ibid.

10. ibid

11. ibid

12. UNCTAD. Global Investment Report, 2009.

13. ibid

14. Malaysia Productivity Corporation, 2009. Productivity Performance of Malaysia. Key Productivity Statistics.

15. ibid

16. ibid

17. World Bank, World Development Indicators, 2009.

18. UNCTAD. Global Investment Report, 2009.

\section{References}

Aitken, B., \& Harrison, A. (1999). Do domestic firms benefit from direct foreign investment? Evidence from Venezuela. American Economic Review, 89(3), 605-18.

Bartlett, C., \& Ghoshal, S. (1989). Managing across borders. The transnational solution. Boston, MA: Harvard Business School Press.

Baumol, W. J., \& McLennan, K. (1985). US productivity performance and its implications. In W. J. Baumol, \& K. McLennan (Eds.), Productivity growth and US competitiveness. New York: Oxford University Press.

Bhatt, P. R. (2008a). Determinants of foreign direct investment in ASEAN. Foreign Trade Review, Vol. XLIII. No. 3, OctoberDecember.

Bhatt, P. R. (2008b). Trade competitiveness and exchange rate policy in ASEAN. Anveshak, 38(2), July-December.

Bhatt, P. R. (2008c). India's trade competitiveness and exchange rate policy. Margin, 2(3), July-September.

Blaine, M. (1993). Profitability and competitiveness: Lessons from Japanese and American firms. California Management Review, Fall 3(1), 48-74.

Blomstrom, M., \& Persson, H. (1983). Foreign investment and spillover efficiency in an underdeveloped economy: Evidence from Mexican manufacturing industry. World development, 11(6), 493-501. 
Caves, R. E. (1974). Multinational firms, competition and productivity in host-country markets. Economica, 42, 176-93.

Choudhri, Eshan, U., \& Lawrence, L. S. (2002). Productivity performance and international competitiveness: An old test reconsidered. Canadian Journal of Economics, 35(2), 341-362.

Chung, W., Mitchell, W., \& Yeung, B. (1998). Foreign direct investment and host country productivity: The American automotive component industry in the 1980s. Mimeo.

Djankov, S., \& Hoekman, B. (1999). Foreign direct investment and productivity growth in Czeck enterprises. World Bank.

Doggett, E., \& Cresswell, J. C. (1979). Aspects of United Kingdom trade competitiveness. Economic Trends. CSO. 304. February.

Driffield, N., \& James, H. L. (2007). Linking FDI motivation and host economy productivity effects: Conceptual and empirical analysis. Journal of International Business Studies, 38, 460-473

Fagerberg, J. (1988). International competitiveness. The Economic Journal, 98(391), 355-374.

Girma, S., \& Wakelin, K. (2001). Regional under development: Is FDI the solution? A semiparametric analysis. Mimeo.

Globerman, S. (1979). Foreign direct investment and spillover efficiency benefits in Canadian manufacturing industries. Canadian Journal of Economics, 12, 42-56.

Government of India, Ministry of Finance. Economic Survey. Various issues.

Heckscher, E. (1919). The effect of foreign trade on the distribution of income. Ekonomisk Tidskriff (pp. 497-512). Translated as chapter 13 in American Economic Association, Readings in the Theory of International Trade (272-300). Philadelphia: Blakiston.

IMF. International Financial Statistics, Annual various issues.

Javorcik, B., \& Spatareanu, M. (2003). To share or not to share: Does local participation matter for spillover from foreign direct investment. World Bank.

Jones, P. T., \& Teece, D. J. (1988). The research agenda on competitiveness in A Furino (Ed.), Cooperation and competition in the global economy. Cambridge: Ballinger Publishing.

Junz, H. B., \& Rudolf, R. R. (1964). Prices and export performance. American statistical association. Proceedings of the Business and Economic Statstics Section.

Kaldor, N. (1967). Strategic factors in economic development (Ithaca, NY: New York State School of Industrial and Labour Relations).

Krugman, P. R. (1983). New theories of trade and industrial countries. American Economics Review, 73(2), 343-47

Krugman, P. R. (1986). Introduction to new thinking about trade policy. In P. R. Krugman (Ed.), Strategic trade policy and the new international economics. Cambridge: MIT Press.

40 IJMS 18 (2), 23-41 (2011) 
Lamfaussy, A. (1963). The United Kingdom and the six. Macmillan.

McGeehan, J. M. (1968). Competitiveness: A survey of recent literature. Economic Journal, 78(310), 243-262.

Ohlin, B. (1933). Interregional and international trade. Cambridge, Mass.: Harvard University Press, 1966.

Parkinson, J. R. (1966). The progress of UK exports. Scottish Journal of Political Economy, February.

Porter, M. E. (1990). The competitive advantage of nations. New York: Free Press.

Porter, M. E., \& Ketels, C.H.M. (2003). UK competitiveness: Moving to the next stage. DTI Economics Paper 3, London, Department of Trade and Industry.

Prahalad, C. K., \& Doz, Y. V. (1987). The multinational mission. New York: Free Press.

Prahalad, C. K., \& Gary, H. (1990). The core competency of the corporation. Harvard Business Review, 74(4), 79-90.

Ricardo, D. (1971). The principles of political economy and taxation. J Murray, London. Originally published in 1817.

Smith, A. (1967). An enquiry into the nature and causes of the wealth of nations. Modern Library New York, originally published in 1776.

Srinivasan, T. N., \& Jessica, W. (2003). Export performance and real effective exchange rate. In A. O. Krueger, \& Sajjd, Z. C. (Eds.), Reforming India's External, Financial, and Fiscal Policies, Stanford University Press. 2003.

Vernon, R. (1966). International investment and international trade in the product cycle. Quarterly Journal of Economics, 80, 190-207. World Economic Forum. (2010). The Report of Global Competitiveness, 2010-11. 